OOPEN ACCESS

International Journal of Management \& Entrepreneurship Research

P-ISSN: 2664-3588, E-ISSN:2664-3596

Volume 2, Issue 5, P.No. 353-364, October, 2020

Fair East Publishers

Journal Homepage: www.fepbl.com/index.php/ijmer

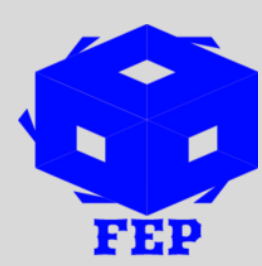

\title{
CONFLICT MANAGEMENT STYLES AND CAREER SATISFACTION IN TERTIARY HEALTH INSTITUTIONS IN RIVERS STATE
}

\author{
Obiageri Felicitas Onwuegbule ${ }^{1}$ \\ ${ }^{1} \mathrm{PhD}$ Candidate, Department of Management \\ Faculty of Management Sciences \\ University of Port Harcourt, Nigeria
}

*Corresponding Author: Obiageri Felicitas Onwuegbule

Corresponding Author Email:obiagerifavour@yahoo.com

Article Received:19-09-20 Accepted: 15-10-20

Published:20-10-20

Licensing Details: Author retains the right of this article. The article is distributed under the terms of the Creative Commons Attribution-NonCommercial 4.0 License (http://www.creativecommons.org/licences/by-nc/4.0/) which permits non-commercial use, reproduction and distribution of the work without further permission provided the original work is attributed as specified on the Journal open access page.

\section{ABSTRACT}

This study examines the relationship between conflict management styles and career satisfaction of tertiary health institutions in Rivers State. Research design is cross-sectional survey. Target population for this study comprises of University of Port Harcourt Teaching Hospital and Braithwaite Memorial Specialist Hospital (BMSH). Purposive sampling technique was used. Total accessible population for this study consists of 608 medical doctors, nurses and administrative staffs. Sample size is 241 using Taro Yamane formular. Method of data collection is questionnaire. 241 copies of questionnaire were distributed but 200 copies were correctly filled and used for data analysis. Validity was determined using face validity. Cronbach alpha test was used to ascertain the reliability of the instrument. Spearman Rank Order Correlation Coefficient (rho) served as a statistical tool. Statistical Package for Social Sciences (22.0) was used to run the analysis. The study found that conflict management styles have significant relationship with career satisfaction. The study concluded that conflict management styles measured in terms of collaboration style, accommodation style and compromise style enhance career satisfaction of health workers in tertiary health institutions in Rivers state. One of the recommendations is that managers should adopt collaboration style of conflict management to resolve disagreement in the organization so as to improve career satisfaction of their employees.

Keywords: Conflict, Conflict Management Styles, Career, Career Satisfaction, Salary, Promotion, Career Development, Collaboration, Accommodation, Compromise 


\section{INTRODUCTION}

Career satisfaction is an indispensable factor in every work that people earn a living. Every employee is always seeking for a good conducive working environment where they can be happy while doing their job. Career satisfaction is the level of overall happiness experienced through one's choice of occupations (Zingeser, 2004). Job can be attractive in pay but may not be attractive with happiness which makes difficult for people not to venture into such jobs. Before one can take a job as career, he/she must have carried out a research about the occupation. Jobs that do not give people the level of innermost satisfaction are always not appreciated by applicants. The health institution is sensitive because of the nature of human life that characterized the profession. In developed nations, health workers are treated with dignity and their welfare cannot be comparable with what is obtainable in Nigeria.

People are still wondering why medical doctors, nurses, laboratory scientist always embark on strikes in Nigeria. The reasons are very clear, upon the delicate nature of their work, most them spent night working just to save human lives in the hospitals. Secondly, government has not shown adequate commitment to equip the hospitals with the latest medical machines that will be used to attend to patients without referring them to private hospital where such equipment can be found. Another indicator why the health workers embark on strike is compensation. They agitate for overtime pay and other forms pay which government has not even met. These are some of the demands that have remained unsolved in the health institutions and this has caused health workers not to be satisfied in their career. Some reasons giving by resident medical doctors includes unhealthy working conditions, infrastructure challenges, optimal management, and poor salaries compared to their counterparts in other countries (Oleribe et al., 2016). There are three major reasons why Nigeria health workers not satisfied with their career; failure by government to honour collective bargaining agreements for improved wages and conditions of service, disempowered' doctors and health care workers who feel unable to provide the best possible care for their patients because of inadequate facilities, and drugs and lack of support by employers especially elected government officials (Osakede\&Ijimakinwa, 2014).

However, there are certain jobs that most people do not want to venture into because of the contents and description. For instance, people that deal on hard drugs may be enjoying the money they are making from the trade but on the one hand, they are not happy with the job because it is against the societal ethics. The joy workers drive from a particular job is tied to their happiness which brings out their best on that job. A lecturer that teaches students may find it very difficult to take up a block moulding job or carpentry job even though these jobs are daily income based compared to his monthly based job. The reason is that no matter how it looks, happiness comes to mind about any job that one wants to take as a career. However, the high rate of unemployment in Nigeria has made people to take up jobs that are not in line with their dream. One who did not love to work with armed forces, police and paramilitary suddenly changes his/he mind to take up such career just because there is no or limited jobs available in the country. Buttressing further, employees that make up the organization cannot be happy with their career if there is conflict within the workplace. Disagreement brings about suspicious between subordinate and the superior manager or supervisor. Conflict can bring about aggression amongst individual members of the organization. Instead of employees 
being happy with their career, conflict can make them unhappy and it will end up creating negative impression amongst members of the organization.

This study however present some previous studies on career satisfaction conducted in different parts of world with their respective findings. Ong et al, (2006) examined the relationship between human resource management practices (training and development, compensation and benefit, performance management) and career satisfaction in Malaysia. The findings of their study revealed that training and development is the most important factor that influence career satisfaction followed by compensation and benefits while performance management was found to be not significant in predicting career satisfaction. Secondly, Amber (2010) carried an empirical study on career satisfaction of young archivists: A survey of professional working archivists, age 35 and under. Amber's results indicate that young archivists are generally satisfied with their day-to-day work. Thirdly, Farzana (2014) examined the relationship between quality of work life dimensions and career satisfaction of the female faculty members working in different private universities in Dhaka, the capital city of Bangladesh. Farzana results revealed that quality of work life dimensions are significantly associated with career satisfaction of female faculties. Finally, Gözükara (207) examined the roles of distributive justice and organizational commitment on career satisfaction. Gözükara's results revealed that mentor role and distributional justice have positive effects on organizational commitment, while organizational commitment positively affects career satisfaction.

From the above trend of studies, it appears that none of them were conducted within the Nigerian work environment and this has created a point of departure. The aim of this study therefore is to examine the relationship between conflict management styles and career satisfaction of tertiary health institutions in Rivers State. To establish the objectives of this study, three conflict management styles will be drawn from the works of Robbins, Judge \&Sanghi, 2009; and Jones and George (2006). These are collaboration, accommodation and compromise. Measures of career satisfaction will be drawn from the work of Greenhaus, Parasuraman \& Wormley (1990). These include salary, promotion and career development.

Nevertheless, one of the sensitive sectors of the Nigerian economy is the health sector. Workers in the health sectors include the medical doctors, nurses, dentists, laboratory scientists and administrative staffs. These workers co-exist harmoniously to achieve common objectives of rendering quality health service delivery to patients and the general public. One critical problem facing the health practitioners is career satisfaction. Most of the health workers are not happy with their jobs due to non-payment of their allowances and monthly salary. Sometimes, government owed these health practitioners for two to three months. This has resulted to strikes upon strikes which have led to deaths of some patients in these hospitals.

However, one other manifestation of the problem is conflict between the management of these tertiary health institutions and the health workers in general. When management tries to protect the interest of government, health workers unions also want to protect the interest of its workers by embarking on strikes. If these workers will be happy, what are the conflict management styles that the management will employed? Would the management accommodate the unions in resolving the conflict? What about collaborating with the unions 
to resolve the disagreements? Or would the management adopt compromise to solve these conflicts between them? These questions will be sought in the next preceding sections.

The aim of this study is to examine the relationship between conflict management styles and career satisfaction in tertiary health institutions in Rivers state. Based on the aim of the study, the specific objectives are:

1. To examine the relationship between collaboration style and salary

2. To examine the relationship between accommodation style and promotion

3. To examine the relationship between compromise style and career development

\section{LITERATURE REVIEW AND HYPOTHESES DEVELOPMENT}

\section{Conflict Management Styles}

Conflict is an indispensable factor in every organization. Conflict is something that cannot be totally eliminated but it can be managed. However, several authors have perceived conflict in different ways. Some defined it based on the environment it exists. Henry (2009) defined organizational conflict as a dispute that occurs when interests, goals or values of different individuals or groups are incompatible with each other. Weihrich (1992) perceived conflict as part of organizational life and may occur between individuals, between the individual and the group, and between groups.

\section{Causes of Organisational Conflict}

There are several factors that cause conflict in the organization. Havenga (2002) submitted that conflict can arise in the organization through; resource availability; affirmative action programs; the scope and content of workload; the introduction of new management techniques; and differences of a cultural and racial nature. Osabiya (2015) on the other hand highlighted the following five causes of conflict in both public and private organizations in Nigeria.

1) Differences in background: Luthans \&Kreitner (1985) emphasized that people in the work place may differ in their background, age, education level attained, work experience and social relations. Studies on conflict have revealed that general, the potential for interpersonal and inter-group conflict is highest when organization members differ markedly in the characteristic decrease the inter-personal report and collaboration between unit representatives in organization.

2) Difference in Value: Values are the very core of individual personalities and deeply affect people's thought and actions for example professionals such as medical doctors and teacher' value freedom and autonomy, but their subordinate believe in closely watching over their work as subordinates.

3) Difference in Personal Trait/Behaviour: In an organization setting people differ in terms of such personality like authoritarianism, dogmatism, hostility, aggressiveness, self-esteem, reaction to provocation and predisposition to distrust and suspicion.

4) Difference in Perceptions: Perception is the way people view issues differing perception over what constitutes reality between individuals and groups is also a major source of interpersonal or inter-group conflict. Differences in perception precipitates disagreement hinder inter-group report and make co-operation and joint decision making impossible. Communication problems, different goals status incongruent etc can result to difference in perception. 
5) Poor Communication Skills: People also differ in communication skills and ability simple misunderstanding that maybe a source of conflict between individuals or group may erupt from the inability to articulate ones position clearly to others.

To manage conflict within the organization, Knippen\& Green (1999) cited in Henry (2009) argued that the best way to handle conflicts objectively is to follow six processes: describing the conflict situation to the other person; asking the other person how he sees the conflict situation; responding the way the other person sees the situation; jointly deciding how to resolve the conflict; making commitment to resolve the conflicts; and promising to be committed in future to continue resolving conflicts which might arise. On the other hand, Derr (1975) argued that contingency theory is one of the conceptual tools useful for managing organizational conflicts. He stressed that there are three major conflict management approaches from which intervener can draw to formulate an approach appropriate for resolving a dispute; collaboration: This process involves people surfacing their differences (get them out in the open) and then work on the problems until they have attained mutually satisfactory solutions. Hotepo, et al (2010) asserts that this approach assumes that people will be motivated to expend the time and energy for such problem-solving activity. Bargaining: This approach assumes that neither party will emerge satisfied from the confrontation but that both, through negotiation, can get something they do not have at the start, or more of something they need, usually by giving up something of lesser importance. One party generally wins more than the other; by the skillful use of tactical trades, he can get the maximum possible from the other side (Hotepo, et al, 2010). (3) Power play: Whereas, in collaboration and bargaining the two sides come together to try to resolve their problems, power play is the dominant mode, the actions are unilateral or in coalitions acting unilaterally (Hotepo, et al, 2010).

Organisational behaviorist Kohlrieser (2006) highlighted six essential skills for managing conflict effectively: create and maintain a bond even with your 'adversary'; establish a dialogue and negotiate; "put the fish on the table"; understand what causes conflict; use the law of reciprocity; and build a positive relationship. From the above conflict management processes, Robbins, Judge \&Sanghi (2009); and Jones \& George (2006) agreed that conflict can be effectively managed through the following:

1. Competition style: When one person seeks to satisfy his or her own interests, regardless of the impact on the other parties to the conflict, that person is competing (Robbins, Judge \&Sanghi, 2009). Competition occurs when each party to a conflict tries to maximize its own gain and has little interest in understanding the other party's position and arriving at a solution that will allow both parties achieve their goals (Jones \&George, 2006).

2. Collaboration style: When the parties to conflict each desire to fully satisfy the concerns of all parties, there is cooperation and a search for a mutually beneficial outcome (Robbins, Judge \&Sanghi, 2009). Jones \& George (2006) asserts that in collaboration, parties to a conflict try to satisfy their goals without making any concession until a reasonable resolution of the conflict is reached.

3. Avoiding style: A person may recognize that a conflict exists and want to withdraw from it or suppress it (Robbins, Judge \&Sanghi, 2009). In avoidance, the two parties to 
a conflict try to ignore the problem and do nothing to resolve the disagreement (Jones \& George, 2006).

4. Accommodation style: When one party seeks to appear an opponent, that party may be willing to place the opponent's interests above his or her own (Robbins, Judge $\&$ Sanghi, 2009). When accommodation takes place, one party to the conflict simply gives in to the demand of the other party (Jones \& George, 2006).

5. Compromise style: When each party to a conflict seeks to give up something, sharing occurs, resulting in a compromised outcome (Robbins, Judge \&Sanghi, 2009). Compromise is possible when each party is concerned about not only its own goal accomplishment but also the goal accomplishment of the other party and is willing to engage in a give-and-take exchange and make concession until a reasonable resolution of the conflict is reached (Jones \& George, 2006).

From the above conflict management styles, the following hypotheses were formulated.

HO1: There is no significant relationship between collaboration style and salary

HO2: There is no significant relationship between accommodation style and promotion

HO3: There is no significant relationship between compromise style and career development

\section{Career Satisfaction}

Career satisfaction measures the extent to which individuals believe their career progress is consistent with their own goals, values and preferences (Erdogan, Kraimer\& Liden, 2004; Heslin, 2003; Seibert \&Kraimer, 2001). Greenhaus, Parasuraman \& Wormley (1990) perceived career satisfaction as the satisfaction originating from extrinsic and intrinsic aspects of a person's career to include salary, advancement and opportunity for career development. Lounsbury, Steel, Gibson \&Drost (2008) viewed career satisfaction as an employee's satisfaction or dissatisfaction about her/his career. Hofmans, Dries \&Pepermans (2008) perceived career satisfaction as a subjective assessment regarding the choice and development of a profession. For Judge, Cable, Boudreau \&Bretz (1995) career satisfaction is broader than satisfaction just with the job; it encompasses both internal and external aspects of the profession. Distinguishing between job satisfaction and career satisfaction, Judge and Kammeyer-Mueller (2007) elucidates that job satisfaction involves the instantaneous affective reactions of employees to their work; while career satisfaction reflects a whole evaluation of the profession including the past and the future.

Career satisfaction is considered an important factor due to its relation to career success, specifically subjective career success that refers to one's emotional and psychological assessment of her/his accomplishments related to career (Siebert \&Kraimer, 2001). Gulsah (2014) stressed that employees' career satisfaction reflects how they feel about their careerrelated roles, accomplishments and success. Barnett \& Bradley (2007) postulates that important indicators of career satisfaction comprises of goal-specific environmental support and resources which provide social and material support for an employee's personal goals. Career satisfaction has been found to be a product of a variety of job-experience factors including salary progression (Seibert, Crant, \&Kraimer 1999), mentoring (Allen et al. 2004), hours worked (Wallace, 2001) and satisfaction with the opportunity to achieve career goals (Reitman \&Schneer 2003). 


\section{Measures of Career Satisfaction}

There are several indicators of career satisfaction but this study adopted its factors from the work of Greenhaus, Parasuraman \& Wormley (1990) who viewed career satisfaction as the satisfaction originating from extrinsic and intrinsic aspects of a person's career to include salary, promotion and career development. Salary here refers to financial reward that a worker is entitled to at the end of the month as in the case of Nigeria law. Promotion refers to the movement from one level of position to a higher level with benefits. Career development refers to processes that can be used to improve the skills of workers. These include training, on-the-job training, off-the-job training, workshops and conferences.

\section{RESEARCH METHODOLOGY}

Research design adopted is cross-sectional survey. Target population for this study comprises of tertiary health instructions in Rivers State which are University of Port Harcourt Teaching Hospital and Braithwaite Memorial Specialist Hospital (BMSH). Total population for this study consists of 608 comprises of medical doctors, nurses and administrative staffs. Purposive sampling technique was employed. Sample size is 241 using Taro Yamane formular. Questionnaire. 241 copies of questionnaire were distributed but 200 copies were correctly filled and used for data analysis. Validity was determined using face validity. Cronbach alpha test was used to ascertain the reliability of the instrument. Spearman Rank Order Correlation Coefficient (rho) served as a statistical tool. Statistical Package for Social Sciences (22.0) was used to run the analysis.

\section{RESULTS AND DISCUSSIONS}

Table 1

\begin{tabular}{ll} 
Reliability Results & \\
\hline Variables & $\boldsymbol{\alpha}$ Coefficients \\
\hline Collaboration & 0.72 \\
Accommodation & 0.81 \\
Compromise & 0.75 \\
Salary & 0.84 \\
Promotion & 0.78 \\
Career development & 0.73 \\
\hline
\end{tabular}

Source: SPSS Output (2020)

Table 2

Gender of Participants

\begin{tabular}{|c|c|c|c|}
\hline \multicolumn{2}{|c|}{ Gender } & \multirow{2}{*}{$\begin{array}{l}\text { Respondents } \\
132\end{array}$} & \multirow{2}{*}{$\begin{array}{l}\text { Percentage (\%) } \\
66\end{array}$} \\
\hline Valid & $\mathrm{M}$ & & \\
\hline & $\mathrm{F}$ & 68 & 34 \\
\hline & Total & 200 & 100 \\
\hline
\end{tabular}

Table 2 above shows the gender of 200 respondents from the tertiary health institutions in Rivers State. 66 out of 200 were males which represent $66 \%$ of the population while 68 out of 200 respondents were females. This means that $66 \%$ of the respondents were males. 
Table 3

Age Brackets of Participants'

\begin{tabular}{cccc}
\hline \multicolumn{1}{c}{ Age } & Respondents & Percentage (\%) \\
\hline Valid & $20-30$ & 30 & 15 \\
& $30-40$ & 118 & 59 \\
& 40 -above & 52 & 26 \\
& Total & 200 & 100 \\
\hline \multicolumn{3}{c}{ Source: Field survey (2020) }
\end{tabular}

Table 3 above shows the age bracket of 200 respondents in tertiary health institutions in Rivers State. 30 out of 200 respondents representing 15\% were between the ages of 20-30 years. Secondly, 118 out of 200 respondents representing $59 \%$ were between the ages of 30 40 years. Thirdly, 52 out of 200 respondents representing $26 \%$ of the total population fall between the ages of 40 years and above. This shows that 118 respondents out of 200 total populations were between the ages of 30-40 years.

Table 4

Occupation of Participants'

\begin{tabular}{clll}
\hline \multicolumn{2}{c}{ Occupation } & Respondents & Percentage (\%) \\
\hline Valid & Medical doctor & 50 & 25 \\
& Nurse & 82 & 41 \\
& Admin & 56 & 28 \\
Dentist & 12 & 6 \\
Total & 200 & 100 \\
\hline \multicolumn{3}{r}{ Source: Field survey (2020) }
\end{tabular}

Table 4 above shows the occupation of 200 respondents in tertiary health institutions in Rivers State. 50 out of 200 respondents representing $25 \%$ were medical doctors. 82 out of 200 respondents representing $41 \%$ were nurses. 56 out of 200 respondents representing $28 \%$ were administrative staffs. 12 out of 200 respondents representing $6 \%$ were dentists. This shows that 82 respondents out of 200 total populations were nurses.

Table 5

Years in Service of Participants'

\begin{tabular}{llll}
\hline \multicolumn{2}{l}{ Years in service } & Respondents & Percentage $(\%)$ \\
\hline Valid & $1-5$ yrs & 52 & 26 \\
& $5-10$ yrs & 102 & 51 \\
& 10 yrs\& above & 46 & 23 \\
& Total & 200 & 100 \\
\hline \multicolumn{2}{r}{ Source: Field survey $(2020)$}
\end{tabular}

Source: Field survey (2020)

Table 5 above shows the number of years in service of 200 respondents in tertiary health institutions in Rivers State. 52 out of 200 respondents representing $26 \%$ have served between 1-5 years. 102 out of 200 respondents representing 51\% have served between 5-10 years. 46 out of 200 respondents representing $23 \%$ have served between 10 years and above. This implies that 102 respondents out of 200 total populations have served between 5-10 years.

Table 6

Educational Qualifications of Participants'

\begin{tabular}{llll}
\hline \multicolumn{2}{c}{ Education } & Respondents & Percentage (\%) \\
\hline Valid & OND/HND & 24 & 12 \\
B.Sc & & 108 & 54 \\
& MBBS & 50 & 25 \\
& BDS & 18 & 9 \\
& Total & 200 & 100 \\
\hline \multicolumn{3}{r}{ Source: Field survey (2020) }
\end{tabular}


Table 6 above shows the educational qualifications of 200 respondents in tertiary health institutions in Rivers State. 24 out of 200 respondents representing 12\% holds OND/HND certificates. 108 out of 200 respondents representing 54\% hold B.Sc degrees. 50 out of 200 respondents representing 25\% holds MBBS. 18 out of 200 respondents representing $9 \%$ holds BDS. This implies that 108 respondents out of 200 total populations holds B.Sc degrees.

\section{Test of Hypotheses}

HO1: There is no significant relationship between collaboration style and salary

Table 7

\section{Correlation}

\begin{tabular}{|c|c|c|c|}
\hline \multirow{2}{*}{\multicolumn{2}{|c|}{ Spearman's rho collaboration Correlation Coefficient }} & \multicolumn{2}{|c|}{ Collaboration Salary } \\
\hline & & 1.000 & $.822^{* *}$ \\
\hline \multirow{5}{*}{ salary } & Sig. (2-tailed) & . & .000 \\
\hline & $\mathrm{N}$ & 200 & 200 \\
\hline & Correlation Coefficient & $.822^{* *}$ & 1.000 \\
\hline & Sig. (2-tailed) & .000 & . \\
\hline & $\mathrm{N}$ & 200 & 200 \\
\hline
\end{tabular}

From the result above, collaboration style has a positive significant relationship with salary. It therefore means that null hypothesis will be rejected and alternate accepted on the basis that pvalue is less than the level of significance (0.05). The study hereby states that there is a significant relationship between collaboration style and salary.

$\mathrm{HO} 2$ : There is no significant relationship between accommodation style and promotion

Table 8

Correlation

\begin{tabular}{clcl}
\hline & & \multicolumn{2}{c}{ Accommodation Promotion } \\
\hline Spearman's rho accommodation Correlation Coefficient & 1.000 & $.718^{* *}$ \\
& Sig. (2-tailed) &. & .000 \\
& $\mathrm{~N}$ & 200 & 200 \\
\multirow{3}{*}{ Promotion } & Correlation Coefficient & $.718^{* *}$ & 1.000 \\
& Sig. (2-tailed) & .000 &. \\
& $\mathrm{~N}$ & 200 & 200 \\
\hline
\end{tabular}

**. Correlation is significant at the 0.05 level (2-tailed).

From the result above, accommodation style has a positive significant relationship with promotion. It therefore means that null hypothesis will be rejected and alternate accepted on the basis that $p$-value is less than the level of significance (0.05). The study hereby states that there is a significant relationship between accommodation style and promotion.

HO3: There is no significant relationship between compromise style and career development 
Table 9

Correlation

\begin{tabular}{|c|c|c|c|}
\hline & & Comp & Caree \\
\hline Spearman's rho Compromise & Correlation Coefficient & 1.000 & $.801^{* *}$ \\
\hline & Sig. (2-tailed) & . & .000 \\
\hline & $\mathrm{N}$ & 200 & 200 \\
\hline Career devt. & Correlation Coefficient & $.801^{* *}$ & 1.000 \\
\hline & Sig. (2-tailed) & .000 & \\
\hline & $\mathrm{N}$ & 200 & 200 \\
\hline
\end{tabular}

From the result above, compromise style has a positive significant relationship with salary. It therefore means that null hypothesis will be rejected and alternate accepted on the basis that pvalue is less than the level of significance (0.05). The study hereby states that there is a significant relationship between compromise style and career development.

\section{Discussion}

Based on the test results above, the study found that conflict management styles have positive significant relationship with career satisfaction. Specifically, it was found that; collaboration style of conflict management has a significant relationship with salary; accommodation style of conflict management has a significant relationship with promotion; and compromise style of conflict management has a significant relationship with career development.

\section{Conclusion}

Based on the findings, the study concluded that conflict management styles measured in terms of collaboration style, accommodation style and compromise style enhances career satisfaction of health workers in tertiary health institutions in Rivers state.

\section{Recommendations}

From the conclusion, the following recommendations were made.

1) Managers should adopt collaboration style of conflict management to resolve disagreement in the organization so as to improve career satisfaction of their employees.

2) Managers of health institutions should employ accommodation style of conflict management to enhance career satisfaction of their workers.

3) Managing Directors of private and government organizations should use compromise style of managing conflict as it has proven the best approach to resolve organisational dispute.

\section{References}

Allen, T.D., Eby, L.T., Poteet, M., Lentz, E., \& Lima, L. (2004). Career benefits associated with mentoring for protégés: A meta-analysis. Journal of Applied Psychology,89(1), 127-36.

Amber, L.C. (2010). Career satisfaction of young archivists: A survey of professional working archivists, Age 35 and Under. The American Archivist, 73 (Fall/Winter 2010), 600625.

Arizona State University Career Services. (2004). Career satisfaction [Research report]. Retrieved Aug. 5, 2004, from http://career.asu.edu/V/researchreportscareersatis.htm 
Barnett, B.R., \& Bradley, L. (2007). The impact of organizational support for career development on career satisfaction. Career Development International, 12(7), 17-636.

Buddhodev, S.A.(2011). Conflict management: Making life easier, The IUP Journal of Soft Skills, 5 (4), 31-43.

Derr, G.B, (1975). Major causes of organizational conflict: Diagnosis for action. Working paper, Naval Postgraduate School, Monterey, California.

Erdogan, B., Kraimer, M.L., \& Liden, R.C. (2004). Work value congruence and intrinsic career success: The compensatory roles of leader-member exchange and perceived organizational support. Personnel Psychology, 57, 305-332.

Farzana, M. (2014).Career satisfaction among female faculty members of private universities in Dhaka city: An evaluation of quality of work life. The Journal of Business in Developing Nations, 13, 2-19.

Gözükara, Z. (2007). From mentoring to career satisfaction: The roles of distributive justice and organizational commitment. Journal of Management and Strategy, 8(1), 61-73.

Greenhaus, J.H., Parasuraman, S., \& Wormley, W.M. (1990). Effects of race on organizational experiences, job performance evaluations, and career outcomes. Academy of Management Journal, 33(1), 64-86.

Gulsah, K. (2014). Career commitment, subjective career success and career satisfaction in the context of hazelnut processing industry in Giresun/Turkey. International Journal of Business and Management, 9(6), 98-105.

Haar, J.M., \& Brougham, D.M. (2013). An indigenous model of career satisfaction: Exploring the role of workplace cultural wellbeing. Social Indicators Research,110(3), 873-890.

Havenga, W. (2002). Conflict management within a local government environment. M.A dissertation, Potchefstroom University. A comparative analysis of conflict dynamics within private and public sector organizations (Phd thesis), Potchefstroom University.

Henry, O. (2009). Organizational conflict and its effects on organizational performance. Research Journal of Business Management, 2(1), 16-24.

Heslin, P.A. (2003). Self and Other-Referent Criteria of Career Success. Journal of Career Assessment, 11(3), 262-286.

Hofmans, J., Dries, N., \&Pepermans, R. (2008). The career satisfaction scale: Response bias among men and women. Journal of Vocational Behavior, 73, 397-403.

Hotepo, O.M., Asokere, S.S., Abdul-Azeez1, I.A, \&Ajemunigbohun, S.S.A. (2010). Empirical study of the effect of conflict on organizational performance in Nigeria. Business and Economics Journal, Volume 2010.

Jones, G.R., Gorge, J.M., \& Hill, C.W.L. (2000). Contemporary Management ( $2^{\text {nd }}$ edn.). Boston: McGraw-Hill.

Judge, T.A., Cable, D.M., Boudreau, J.W., \&Bretz, R.D. (1995). An empirical investigation of the predictors of executive career success. Personnel Psychology,48, 485-519.

Judge, T.A., \&Kammeyer-Mueller, J.D. (2007). Personality and career success. In M. Peiperl \& H. Gunz (Eds.), Handbook of Career Studies, (59-78). Thousand Oaks, CA: Sage.

Knippen, J.T., \& Green, T.B. (1999). Handling Conflicts. Journal of Workplace Learning, 11(1), 27-32. 
Kohlrieser, G. (2006). Hostage at the Table: How Leaders can Overcome Conflict, Influence Others, and Raise Performance (San Francisco: Jossey-Bass), 99-122.

Landon, B.E. (2004). Career satisfaction among physicians. JAMA, 291, 634. Retrieved Aug. 5, 2004, from http://jama.ama-assn.org/cgi/content/full/291/5/634 [Article] [PubMed]

Lounsbury, J.W., Steel, R.P., Gibson, L.W., \&Drost, A.W. (2008). Personal traits and career satisfaction of human resource professionals. Retrieved from http://info.ecareerfit.com/eCareerFit/CareerSatisfaction_HRProfessionals_final2.pdf

Luthans, F., \&Kreitner, R. (1985). Organizational behavior modification and beyond. Glenview, IL: Scott, Foresman

Oleribe, O.O., Ezieme, I.P., Oladipo, O., Akinola, E.P., Udofia, D., \& Taylor-Robinson, S.D. (2016). Industrial action by healthcare workers in Nigeria in 2013-2015: An inquiry into causes, consequences and control - a cross-sectional descriptive study. Human Resources for Health, 14(46), 1-10.

Ong, C.H., Teo, Y.C., Chang, C.Y., Wong, V.G., Siti, M.K., \&Jasveena, R.P. (2006).The Influence of Human Resource Management Practices on Career Satisfaction: Evidence from Malaysia. International Review of Management and Marketing, 6(3), 517-521.

Osabiya, B.J. (2015). Conflict management and resolution in Nigeria public sector. Review of Public Administration and Management, 4(8), 107-120.

Osakede, K.O., \&Ijimakinwa, S.A. (2014). The effect of public sector health care workers strike: Nigeria experience. Review of Public Administration and Management ,3(6).

Reitman, F., \& J.A. Schneer. (2003). The promised path: A longitudinal study of managerial careers. Journal of Managerial Psychology, 18(1), 60-75.

Robins, S.P., Judge, T.A., \&Sanghi, S. (2009). Organizational behavior $\left(13^{\text {th }}\right.$ edn.). New Delhi: Prentice Hall.

Seibert, S.E., Crant, J.M., \&Kraimer, M.L. (1999). Proactive personality and career success. Journal of Applied Psychology,84(3), 416-27.

Seibert, S.E., \&Kraimer, M.L. (2001). The five factor model of personality and career success. Journal of Vocational Behavior, 58, 1-21.

Shehan, J.G., Hadley, R.G., \&Lechleiner, L. (1964). Career satisfaction and recruitment in speech pathology and audiology. Asha, 6, 277-283.

Stone, P.K., Vaden, A.G., \& Vaden, R.E. (1981). Career selection and related variables. Journal of the American Dietetic Association, 79(1), 30-36.

Weihrich H, (1992). Management: A global perspective (11 ${ }^{\text {th }}$ Edn.), Prentice-Hall, Englewood Cliffs, N.J

Zingeser, L. (2004). Career and Job Satisfaction. The ASHA Leader, 9, 4-13. 